\title{
DESCRIPTION OF THREE CAVE DIPLOPODS OF PSEUDONANNOLENE SILVESTRI (DIPLOPODA, PSEUDONANNOLENIDA, PSEUDONANNOLENIDAE)
}

\author{
Carmem Silvia Fontanetti ${ }^{1}$
}

\begin{abstract}
Three new species of Pseudonannolene Silvestri, 1895 diplopods are described: $P$. anapophysis (type locality, "Caverna Lapão", Bahia), P. imbirensis (type locality, "Caverna São Mateus", Imbira III, Goiás), and P. chaimowiczi (Minas Gerais, Bahia)

KEY WORDS. Diplopoda, Pseudonannolene, millipedes, cave fauna, neotropics
\end{abstract}

Diplopods represent a class of the ancient Myriapoda, commonly known as millipedes and vulgarly called "piolho-de-cobra ", "emboa", "gongolo" in Brazil. They are animals of furtive habits that flee from light and live under rocks, tree trunks and leaves, and a few live in symbiosis in ant and termite nests. Because of the habits of this group, caves offer them an suitable habitat. In various studies carried out on Brazilian caves, diplopods have been cited as animals frequently found (DESSEN et al. 1980; Chaimowicz 1984, 1986; Trajano 1987; PINTO-DAROCHA 1995; GNASPINI \& TRAJANO 1994). All species collected thus far belong to two orders: Polydesmida and Pseudonannolenida. The representatives of the latter order belong to the genus Pseudonannolene Silvestri, 1895 and are considered to be troglophiles, i.e., facultative cave dwellers (Trajano 1987). The first Pseudonannolene recorded from caves was P. strinatii Mauriès, 1974, detected by MAURIĖs (1974) in the "Gruta das Areias", Iporanga, São Paulo. The second species, $P$. tocaiensis, was recently described by FONTANETTI (1996) for the "Gruta da Toca", "Fazenda da Toca", Analândia, São Paulo.

Except for these two reports, no other cavernicolous Pseudonannolene species have been described. On the basis of several collections made by Brazilian speleologists, the genus has been found in caves in the States of São Paulo, Minas Gerais, Goiás, Paraná and Bahia.

The material described in this paper was deposited in the collection of the Departamento de Biologia, Instituto de Biociências, Universidade Estadual Paulista (UNESP) (Rio Claro, São Paulo, Brasil).

1) Departamento de Biologia, Instituto de Biociências, Universidade Estadual Paulista. Caixa Postal 199, 13506-900 Rio Claro, São Paulo, Brasil. CNPq researcher. 


\section{Pseudonannolene anapophysis, sp.n.}

Figs 1-4

Holotype. Adult male (no. 561 in the collection). BRAzIL, Bahia: Lençois ("Caverna Lapão"), I-1987, F. Chaimowicz leg.. Paratypes: two females and one young male, at the same site.

Description. robust body (diameter around $5 \mathrm{~mm}$ ), long (around $90 \mathrm{~mm}$ ), with dark coloring in first segments, others striped; prozonae with lighter bands; light antennae and dark legs (observed in material preserved in alcohol).

Head with a sulcus on vertex which crosses the frontal suture. Considerably long antennae covered with very fine bristles. Distinct ocelli lighter than head.

Metazonae of same diameter as prozonae; segments markedly striated on sides. Strong legs.

Anal valves without bristles, with numerous sulci on the posterior margin (Fig. 2).

First legs pair of males (Fig. 1): small coxa whose width is the same as length, all covered with strong bristles; base of coxa is same width as distal portion. All segments are densely covered with strong setae. Prefemur without process, with internal portion in relief and densely covered with strong bristles.

Gonopods (Figs 3, 4). Large coxa approximately twice as long as basal width, with internal part covered with dentiform processes. Telopodite with a wide base that abruptly narrows forming a step; apical portion covered with short bristles. Length of telopodite is approximately four times less than the length of coxa. Solenomerite a little larger than telopodite, directed outward, with squamous distal portion wider than basal portion.

This species has been found only in cave environments.

Discussion. The species differs from all others by the absence of the prefemoral process in the first leg pair of males, marked narrowing of the basal portion of the solenomerite and presence of sulci in the anal valves.

\section{Pseudonannolene chaimowiczi, sp.n.}

Figs 5-7

Holotype. Adult male (no. 580 in the collection). BrazIL, Minas Gerais: Lagoa Santa ("Gruta Helictites"), V-1987. Paratypes: 7 males and 10 females Minas Gerais: Itacarambi ("Gruta Olhos D'Agua"), IV-1985 (no. 85-E), F. Chaimowicz leg.; Lagoa Santa ("Gruta Helictites"), III-1986 (no. 226); Bahia: Campo Formoso, "Convento", I-1987 (no. 513); Santana ("Gruta do Padre", stream conduct), VI-1987 (no. 617-20), F. Chaimowicz leg. .

Description. Robust body (diameter around 3-5mm), long (80-130mm), quite tapered anteriorly, dark coloring in antennae, legs, telson and collum; segments in two shades, with prozonae lighter than metazonae (observed in material preserved in alcohol).

Head with a sulcus on vertex that crosses the frontal suture. Long antennae densely covered with bristles. Ocelli of the same color as head. 

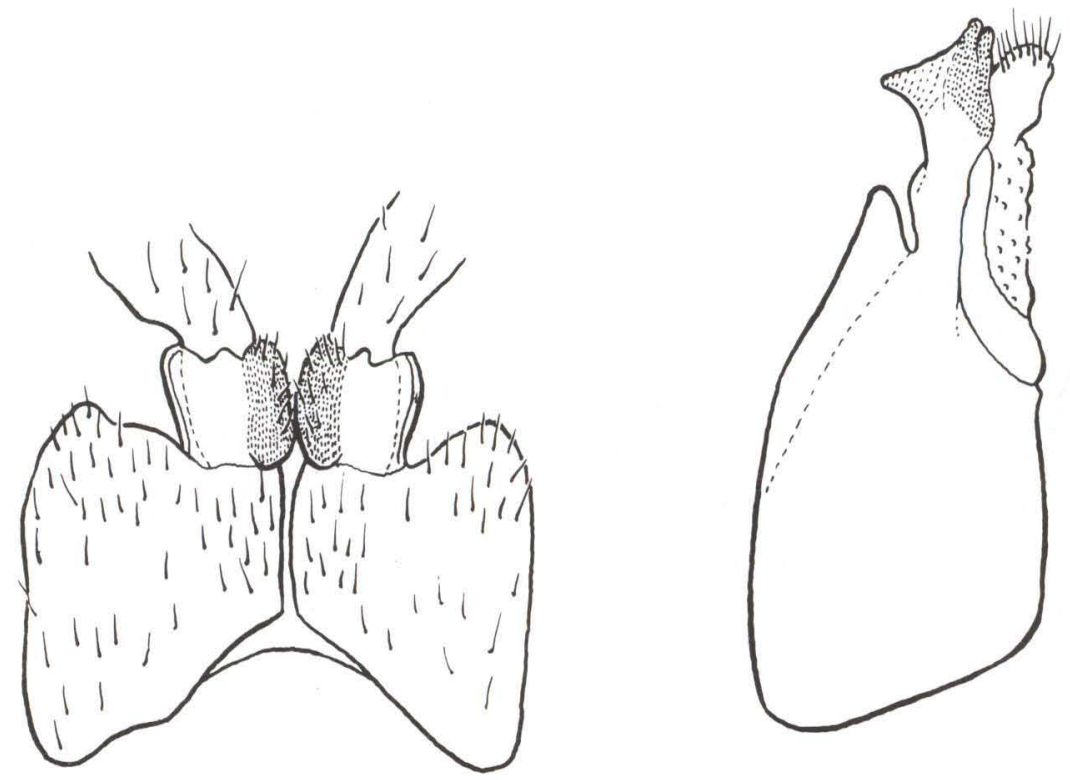

1

(3)
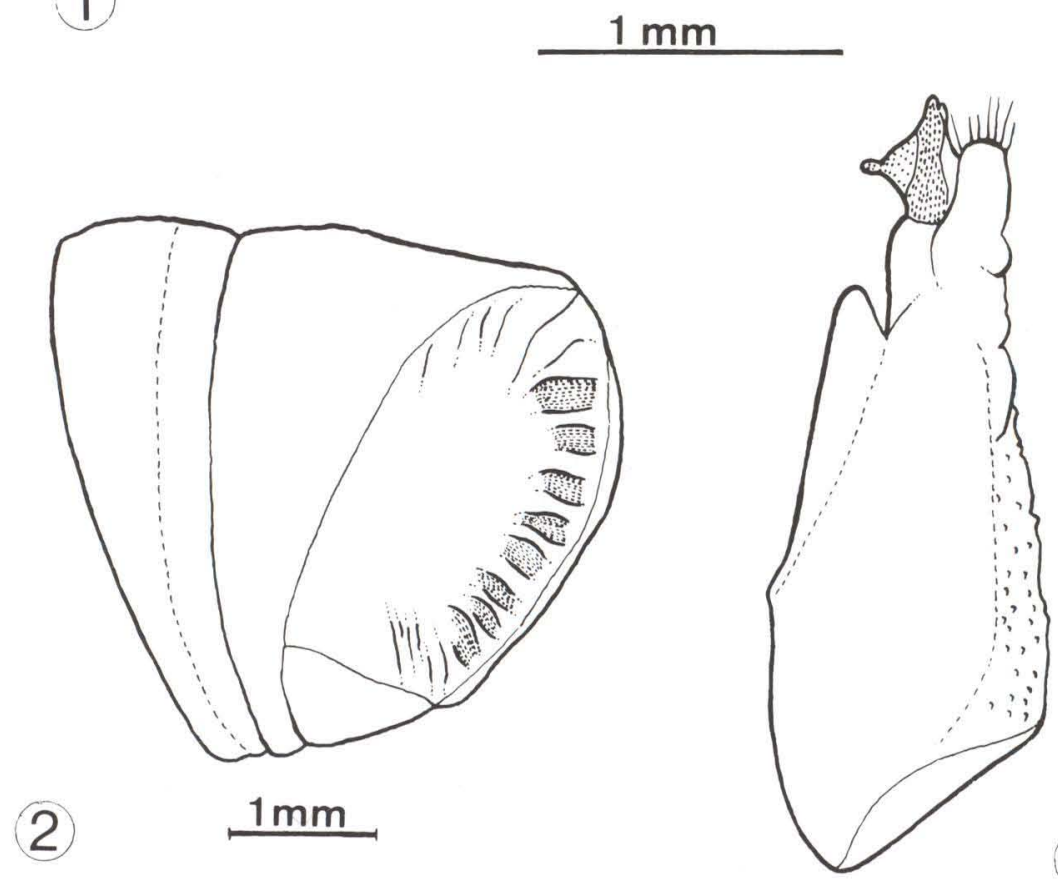

Figs 1-4. Pseudonannolene anapophysis, sp.n.. (1) Oral view of the first leg pair of the male; (2) lateral view of the telson; (3) oral view of the gonopods; (4) caudal view of the gonopods. 
Collum highly striated in lateral portion. Metazonae of a wider diameter than prozonae; considerably striated segments.

Anal valves with margins in relief and in a lighter color, with bristles $(2+2)$.

First legs pair of males (Fig. 5): longer than wider coxa covered throughout with strong bristles; bristles present in larger number in a cluster in the distal portion; coxa with wide base that narrows gradually; base of coxa is twice as wider than distal portion. All segments are densely covered with strong bristles. The prefemur is covered with bristles in the internal portion, with a small process parallel to its pair.

Gonopods (Figs 6, 7). Coxa 1.5 times longer than basal width, internal part covered with series of dentiform processes. Telopodite with wide base that narrows gradually; apical portion covered with strong bristles; telopodite length approximately 3.5 times less than coxa length. Solenomerite longer than telopodite, slightly directed outward; distal portion squamous, tapered at two points and wider than basal portion.

This species is widely distributed in Bahia and Minas Gerais caves.

Discussion. The species differs from Pseudonannolene microzoporus Mauriès, 1987, which occurs in the Lagoa Santa region, by the configuration of the first legs pair ( $P$. microzoportis presents a prefemoral process that is not parallel to its pair, namely divergent) and by the distal portion of the solenomerite, which in $P$. microzoporus does not present the two projections, just one.

\section{Pseudonannolene imbirensis, sp.n.}

Figs 8-10

Holotype. Adult male (no. 0065 in the collection). BrazIL, Goiás: São Domingos ("Caverna São Mateus-Imbira III"), IV-1989, GREGEO (Speleology Group of Geology) leg.. Paratypes: a young male from the same collect (no. 0065); females collected at the same site, VII-1988 (no. 0014).

Description. Medium-sized body (around $60 \mathrm{~mm}$ ), slender (diameter around $2.5 \mathrm{~mm}$ ) tapering anteriorly, of uniform light brown color, prozonae with a slightly lighter band; legs of same color as body; head, collum and telson slightly lighter (observed in specimens preserved in alcohol).

Head with a sulcus on the vertex that does not exceed the frontal suture. Long antennae covered with short bristles. Ocelli of same color as head.

Metazonae of wider diameter than prozonae.

Anal valves with bristles (2+2).

First legs pair of males (Fig. 8): Coxa whose width is the same as length, densely covered with strong bristles in distal region; coxa base twice as wide as distal portion. All segments are densely covered with bristles. Large prefemur covered with bristles only in internal median portion, with small process not parallel to its pair, namely divergent.

Gonopods (Figs 9, 10). Coxa 1.5 times wider than basal width, internal part covered with a series of dentiform processes. Telopodite with wide base that narrows gradually; median-apical portion covered with short bristles; telopodite 

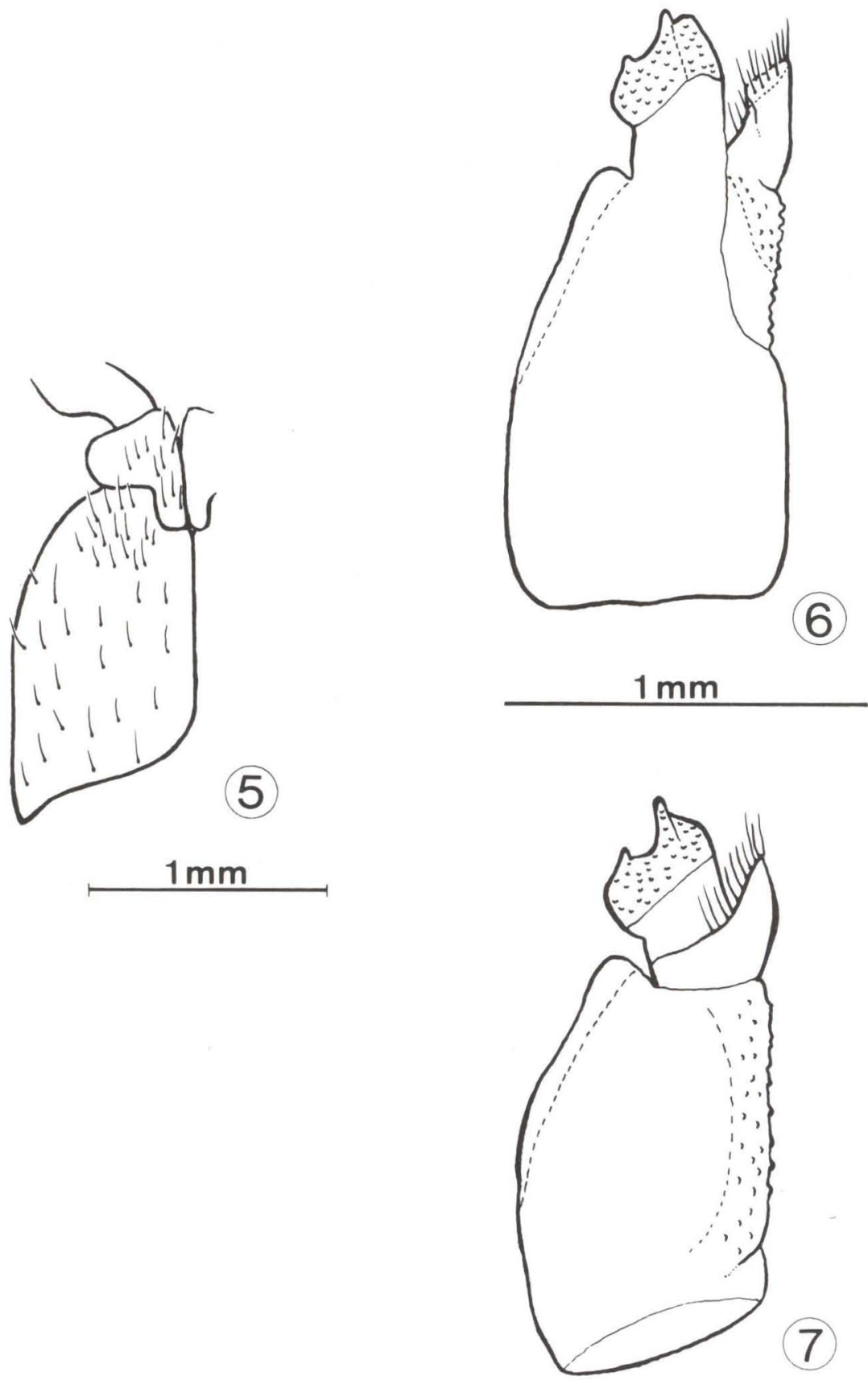

Figs 5-7. Pseudonannolene chaimowiczi, sp.n.. (5) Oral view of the first leg pair of the male; (6) oral view of the gonopods; (7) caudal view of the gonopods. 
length about three times less than coxa. Solenomerite larger than telopodite, slightly directed outward; squamous distal portion tapering at two points, of same width as basal portion.

The species has been detected only in cave environments.

Discussion. Although this species is closely similar to P. chaimowiczi in terms of gonopod configuration, the two species differ in the first legs pair of males (compare figures 5 and 8 ) and in size, with $P$. chaimowiczi being larger than $P$. imbirensis, presenting specimens much larger than the standard for the genus, at certain localities (in Lagoa Santa, "Gruta Helictites" $=130 \mathrm{~mm}$ ).
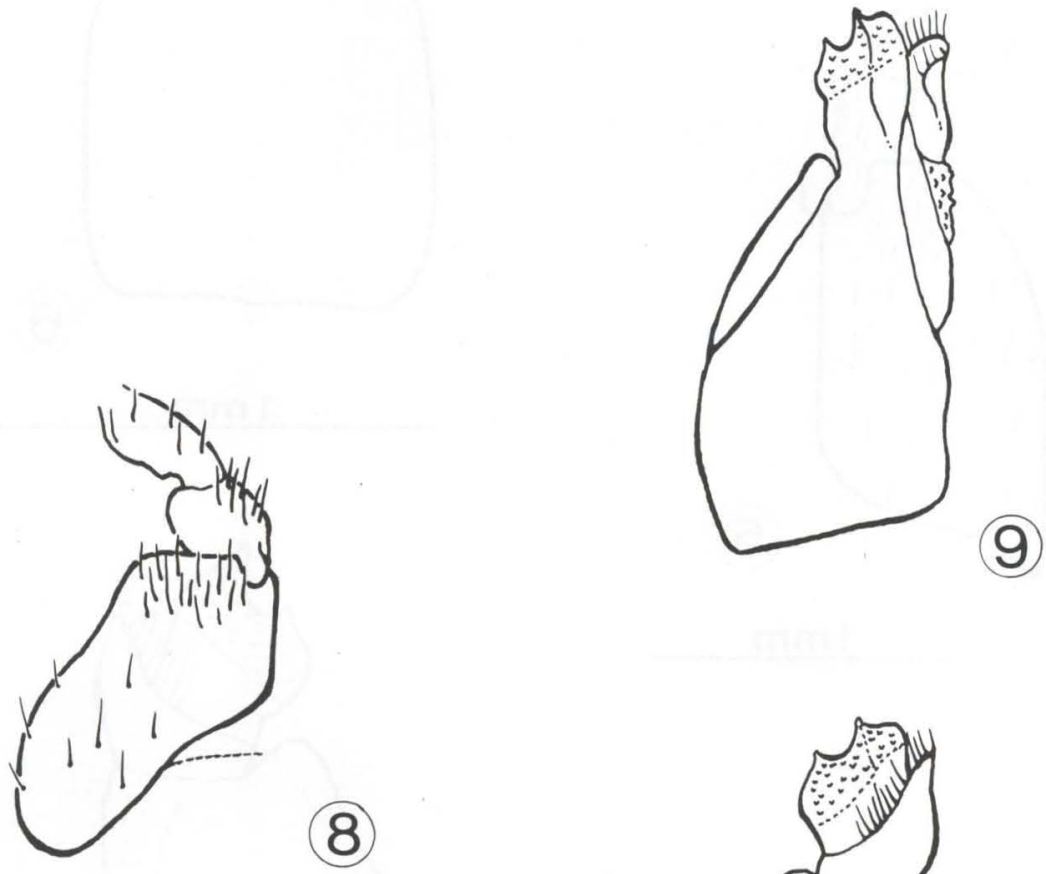

\section{$1 \mathrm{~mm}$}

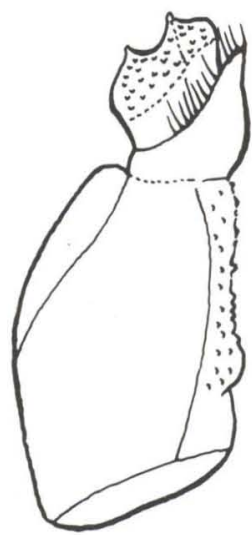

Figs 8-10. Pseudonannolene imbirensis, sp.n.. (8) Oral view of the first leg pair of the male; (9) oral view of the gonopods; (10) caudal view of the gonopods. 
ACKNOWLEDGMENTS. I am particularly grateful to Prof. Alejo Mesa and Prof. Miriam M.O. Levada for guidance and suggestions, to Flávio Chaimowicz, Ricardo Pinto-da-Rocha and Eleonora Trajano for sending me the material to be studied, and to CNPq and FAPESP for financial support.

\section{REFERENCES}

Chaimowicz, F. 1984. Levantamento bioespelológico de algumas grutas de Minas Gerais. Espeleotema (Soc. bras. Espeleol.) 14: 97-107.

. 1986. Observações preliminares sobre o ecossistema da Gruta Olhos d'Água, Itacarambi, MG. Espeleotema (Soc. bras. Espeleol.) 15: 65-77.

Dessen, E.M.B.; V.R. Eston; M.S. Silva; M.T. Temperini-BeCK \& E. TRAJano. 1980. Levantamento preliminar da fauna de cavernas de algumas regiões do Brasil. Ciênc. \& Cult. 32 (6): 714-725.

FonTANETTI, C.S. 1996. Description of the new species and karyotype of the cavernicolous millipede Pseudonannolene Silvestri and the karyotype of Pseudonanolene strinatii Mauriès, 1974 (Diplopoda, Pseudonannolenida, Pseudonannolenidae). Revta bras. Zool. 13 (2): 419-426.

GNASPINI, R. \& E. TRAJANO. 1994. Brazilian cave invertebrates, with a checklist of troglomorphic taxa. Revta bras. Ent. 38 (3/4): 549-584.

MAuriés, J.P. 1974. Um cambalide cavernicole du Bresil, Pseudonannolene strinatti n.sp. (Myriapoda, Diplopoda). Rev. suisse. Zool. 81 (2): 545-550.

PINTO-DA-RochA, R. 1995. Sinopse da fauna cavernícola do Brasil 1907-1994. Papéis Avulsos Depto. Zool., São Paulo, 39 (6): 61-173.

TRAJANO, E. 1987. Brazilian cavernicolous fauna preliminary composition and characterization. Revta bras. Zool. 3 (8): 533-562.

Recebido em 28.III.1996; aceito em 11.X.1996. 